seen that there are circumstances where it is not unreasonable. In the first of the two suggested categories, the attorney general was in effect seeking to uphold the validity of a statute by urging the unconstitutionality of alternative interpretations. In the second, decisions of the Supreme Court indicate quite clearly a willingness to allow an attorney general-where private persons could not- to invoke the Constitution to attack legislation which he believes seriously impairs the best interests of the government. As the cases in this area have been, and undoubtedly will be, very limited in number, the exact extent of this right of an attorney general will probably not be fuily developed. It would seem, however, that the Court would have experienced no difficulty in granting standing to the Alaska Attorney General to argue the unreached constitutional issue in the American Can Co. case.

\title{
FULL FAITH AND CREDIT TO FOREIGN INJUNCTIONS
}

It is not unusual for a court of general jurisdiction in one state $\left(F_{1}\right)^{1}$ having jurisdiction of the parties residing therein, to enjoin one of them (A) from suing the other $(B)$ in the courts of a sister state $\left(F_{2}\right){ }^{2}$ Typically, however, a court of $F_{1}$ will restrain $A$ from suing $B$ in the courts of $F_{2}$ only in the following cases: where the action in $\mathrm{F}_{2}$ would evade the exemption laws of $\mathrm{F}_{1} ;^{3}$ where it was

1 For the sake of clarity $F_{1}$ shall be used throughout this comment to signify the enjoining jurisdiction, and $\mathrm{F}_{2}$ shall represent the jurisdiction wherein the prosecution has been enjoined. The letters $A$ and $B$ shall stand for the enjoined and enjoining parties respectively.

2 E.g., Cole v. Cunningham, 133 U.S. 107 (1890); Weaver v. Alabama Great So. R. Co., 200 Ala. 432, 76 So. 364 (1917); Morgan v. Amick, 102 Ind. App. 603, 4 N.E.2d 51 (1936); Natalbany Lumber Co. v. McGraw, 188 La. 863, 178 So. 377 (1938). English courts have enjoined residents from suing in foreign jurisdictions on numerous occasions, see Ellerman Lines v. Read [1928] 2 K.B. 144; Portarlington v. Soulby, 3 My. \& K. 104 (1834); Harrison v. Gurney, 2 Jac. \& W. 563 (Ch., 1821). In regard to injunctions issuing against FELA suits in state or federal courts of other states, see Pope v. Atlantic Coast Line R. Co., 345 U.S. 379 (1953); Miles v. Illinois Central R. Co., 315 U.S. 698 (1942); Baltimore \& Ohio R. Co. v. Kepner, 314 U.S. 44 (1941). Concerning injunctions by federal courts against state proceedings, see 62 Stat. 968 (1948), 28 U.S.C.A. \$2283 (1950).

${ }^{3}$ Many states will enjoin the prosecution of an action in a sister state, where that suit was brought to evade a protection afforded the law defendant by the enjoining state's law. See Dehon v. Foster, 86 Mass. (4 Allen) 545, 552-53 (1862), where Bigelow, C. J., says: "The defendants, being citizens of this state, are bound by its laws. They cannot be permitted to do any acts to evade or counteract their operation, the effect of which is to deprive other citizens of rights which those laws are intended to secure. . . By interposing to prevent it, we do not interfere with the jurisdiction of courts in other states, or control the operation of foreign laws. We only assert and enforce our own authority over persons within our jurisdiction, to prevent them from making use of means by which they seek to countervail and escape the operation of our own laws, in derogation of the rights and to the wrong and injury of our own citizens." Accord: Weaver v. Alabama Great So. R. Co., 200 Ala. 432, 76 So. 364 (1917); O'Haire v. Burns, 45 Colo. 432, 101 Pac. 755 (1909); Wilson v. Josephs, 107 Ind. 490, 8 N.E. 616 (1886); Teager v. Landsley, 69 Iowa 725 (1886); Wierse v. Thomas, 145 N.C. 261, 59 S.E. 58 (1907); Bigelow v. Old Dominion Copper Mining \& Smelting Co., 74 N.J.Eq. 457, 71 Atl. 153 (1908). 
brought in $\mathrm{F}_{2}$ in order to vex or harass $\mathrm{B} ;{ }^{4}$ or where it would result in additional expense and inconvenience to $B$, which could be avoided by its being brought in $\mathrm{F}_{1} .^{5}$

Despite unanimity of both federal and state authorities as to the permissibility of such a decree, ${ }^{6}$ there is little certainty as to the effect to be given it by the second state. ${ }^{7}$ The Constitution requires that "Full Faith and Credit ... be given in each State to the public Acts, Records and judicial Proceedings of every other State"8 and is implemented by a statute which provides:

Such Acts, records and judicial proceedings ... shall have the same full faith and credit in every court within the United States and its Territories and Possessions as they have by law or usage in the courts of such State, Territory or Possession from which they are taken. ${ }^{9}$

"Judicial proceedings" appears without limitation in both the Clause and its implementing statute, and would thus seem to include injunctions as well as other kinds of judgments. ${ }^{10}$ In the absence of a Supreme Court decision requiring that full faith and credit be given these injunctions or congressional action forcing their recognition, however, courts have not felt compelled to accord these injunctions such credit.11 In those few instances where recognition has been extended to these judgments by the courts of a sister state, ${ }^{12}$ it

${ }^{4}$ E.g., Poole v. Mississippi Publishers Corp., 208 Miss. 364, 44 So.2d 467 (1950); Wabash Ry. Co. v. Peterson, 187 Iowa 1331, 175 N.W. 523 (1919).

${ }^{5}$ See Baltimore \& Ohio R. Co. v. Bole, 31 F.Supp. 221 (N.D.W.Va., 1940); Ex parte Crandall, 52 F.2d 650 (S.D.Ind., 1931), aff'd 53 F.2d 969 (C.A. 7th, 1931), cert. denied 285 U.S. 540 (1932) (FELA action brought in Missouri on death occurring in Tennessee, injunction issued on the basis of the cost of transporting witnesses to the trial); Cleveland,C.C. \& St.L.Ry.Co.v. Shelly, 96 Ind. App. 273, 170 N.E. 328 (1930). But see Chesapeake \& O. R. Co. v. Vigor, 90 F.2d 7 (C.A.6th, 1937) (added expense and inconvenience insufficient to warrant an injunction), cert. denied 302 U.S. 705 (1937); Southern Pacific R. Co. v. Baum, 39 N.M. 22, 38 P.2d 1106 (1934).

${ }^{6}$ See cases cited note 2 supra.

${ }^{7}$ James v. Grand Trunk W. R. Co., 14 III.2d 356, 152 N.E.2d 858 (1958) (prompted counter-injunction); Nicholas \& Shepard Co. v. Wheeler, $150 \mathrm{Ky}, 169,150$ S.W. 33 (1912) (sister state injunction held no bar); State ex rel. Bossung v. District Court, 140 Minn. 494, 168 N.W. 589 (1918); Union Pacific R. Co. v. Rule, 155 Minn. 302, 192 N.W. 161 (1923); Kepner v. Cleveland, C.C. \& St.L. Ry. Co., 322 Mo. 299, 15 S.W.2d 825 (1929) (evidence of foreign injunction not admitted). For cases recognizing the injunction to the extent of dismissing the suit, see Allen v. Chicago, Great W. R. Co., 239 Ill. App. 38 (1925); Equitable Life Assurance Soc. v. Gex' Estate, 184 Miss. 577, 186 So. 659 (1939); Fisher v. Pacific Mutual Life Ins. Co., 112 Miss. 30, 72 So. 846 (1916).

8 U.S. Const. Art. 4, $\$ 1$.

9 62 Stat. 947 (1948), 28 U.S.C.A. \$1738 (1950).

${ }^{10}$ Report, Standing Committee on Jurisprudence \& Law Reform, 52 A.B.A. Reports 292, 294-95 (1927).

"See cases cited note 7 supra.

${ }^{12}$ See Allen v. Chicago, Great W. R. Co., 239 Ill. App. 38, 43 (1925); Equitable Life Assurance Soc. v. Gex' Estate, 184 Miss. 577, 186 So. 659 (1939); Fisher v. Pacific Mutual 
has been based on comity rather than on the constitutional command of full faith and credit. Notwithstanding these instances of voluntary recognition, it is to be suggested by this comment that the courts of $F_{2}$ are required by the Full Faith and Credit Clause to recognize an injunction issued by the courts of $F_{1}$ by dismissing the action whose prosecution has been enjoined..$^{13}$

Exemplifying the typical factual context giving rise to arguments for and against the extension of full faith and credit to these decrees are the cases of Union Pacific R. Co. ข. Rule ${ }^{14}$ and James ข. Grand Trunk W. R. Co. ${ }^{15}$ In the Rule case, B, a Utah corporation having a residence in Iowa, obtained an injunction from the courts of that state against $A$, another resident of Iowa, restraining A from prosecuting a suit in Minnesota for a personal injury sustained in Iowa. Iowa was thus the resident state of both the plaintiff and defendant, the place where the cause of action arose and the probable home of all the witnesses. Though Minnesota had no interest in providing a forum for this litigation, the Minnesota court refused to dismiss.

Difficulty in comprehending the policy considerations behind that court's refusal to dismiss is increased by the fact that it declined to take jurisdiction in International Milling Co.v. Columbia Transportation $\mathrm{Co} .{ }^{16}$ although the plaintiff, a foreign corporation, conducted most of its business in Minnesota. The court in refusing jurisdiction rested its decision on the ground that entertaining the action would burden interstate commerce, but it is nevertheless clear that the reasons for refusing jurisdiction in that case are parallel to the ideas underlying the now well established doctrine of forum non conveniens, ${ }^{17}$ i.e., a court will

Life Ins. Co., 112 Miss. 30, 72 So. 846 (1916); Gilman v. Ketcham, 84 Wis. 60, 65-6, 54 N.W. 395, 396 (1893), where Pinney, J., said for the Wisconsin court:

"There is nothing in the statute of New York, or in this proceeding under it, in conflict with or in contravention of the laws or public policy of this state ... nor does the present proceeding interfere, or tend to interfere, with or prejudice the rights of any citizen of this state. The case concerns citizens of New York alone... [and] is therefore free from all objections which, by the general current of authority, might prevent or induce the courts of Wisconsin to refrain from giving, in a spirit of just interstate comity, the same force and effect here to the proceedings in the supreme court of the state of New York in question as would be accorded them there."

${ }^{13}$ See Currie, The Constitution and the Choice of Law: Governmental Interests and the Judicial Function, 26 U. of Chi. L. Rev. 9 (1958); Currie, Full Faith and Credit to Foreign Land Decrees, 21 U. of Chi. L. Rev. 620 (1954); and Currie, The Constitution and the "Transitory" Cause of Action, to appear in Volume 73 of the Harvard Law Review.

14155 Minn. 302, 193 N.W. 161 (1923).

1514 IIl.2d 156, 152 N.E.2d 858 (1958).

${ }^{16} 189$ Minn. 507, 250 N.W. 186 (1933).

${ }^{17}$ See Gulf Oil Corp. v. Gilbert, 330 U.S. 501, 508-9 (1947), where the criteria for dismissal on grounds of forum non conveniens were established for the federal courts, e.g., the nature of the interest which the plaintiff is seeking to enforce, the availability of witnesses and evidence, whether plaintiff is a resident, whether the law of the forum governs the facts of the case, and whether the cause of action arose in the forum. See also, Currie, Change of Venue and the Conflict of Laws, 22 U. of Chi. L. Rev. 620 (1954); Barrett, The Doctrine of Forum Non Conveniens, 35 Calif. L. Rev. 380 (1947). 
decline to adjudicate a case, although it has "jurisdiction," where it lacks interest in the litigation as determined by such factors as the residence of the parties, the place where the cause of action arose and the availability of witnesses. Although International Milling was later reversed by the United States Supreme Court ${ }^{18}$ and the Minnesota court held a proper forum for the litigation, it would appear that the Supreme Court decision might be attributed to the fact that the plaintiff was a resident of Minnesota. If the litigation had arisen between non-residents on a foreign cause of action it would seem unlikely, in light of the Supreme Court's decision in Davis v. Farmers Co-operative Equity Co., ${ }^{19}$ that Minnesota would have been an appropriate forum to entertain the suit:

... orderly, effective administration of justice clearly does not require that a foreign carrier shall submit to a suit in a State in which the cause of action did not arise, in which the transaction giving rise to it was not entered upon... and in which the plaintiff does not reside. ${ }^{20}$

The policy considerations which led to the Minnesota court's refusal to exercise jurisdiction in International Milling appear to be all the more applicable to the Rule case, where Minnesota was neither the state of residence of the parties nor the jurisdiction where the cause of action arose.

Similarly, in James v. Grand Trunk W. R. Co., the Illinois Supreme Court, absent the foreign injunction, might have dismissed the suit on grounds of forum non conveniens. ${ }^{21}$ There a Michigan administratrix had been enjoined by the courts of Michigan from prosecuting a wrongful death action in the courts of Illinois. Disopeying the Michigan decree the administratrix continued her action in Illinois, and in addition succeeded in persuading the Illinois Supreme Cuurt to enjoin the defendant railway company from enforcing its Michigan injunction. The residence of the parties, the accident, the witnesses and the law that governed were associated with Michigan and not Illinois. By

${ }^{18}$ International Milling Co. v. Columbia Transportation Co., 292 U.S. 511 (1934). See McGowan, Litigation as a Burden on Interstate Commerce, 33 Ill. L. Rev. 875 (1939); Farrier, Suits against Foreign Corporations as a Burden on Interstate Commerce, 17 Minn. L. Rev. 381 (1933).

${ }^{19} 262$ U.S. 312 (1923).

${ }^{20} \mathrm{Id}$., at 317 .

${ }^{21}$ James v. Grand Trunk W. R. Co., 14 Ill.2d 356, 372, 152 N.E.2d 858, 867 (1958), where Bristow, J., speaking for the Illinois court said that "if Illinois were not the appropriate forum to try this, or any other transitory action, the defense of forum non conveniens could be interposed, and, if meritorious, the Illinois court would dismiss the case. However, this court need not, and will not, countenance having its right to try cases, of which it has proper jurisdiction, determined by the courts of other States, through their injunctive process. We are not only free to disregard such out-of-State injunctions, and to adjudicate the merits of the pending action, but we can protect our jurisdiction from such usurpation by the issuance of a counterinjunction restraining the enforcement of the out-of-State injunction."

See also Whitney v. Madden, 400 Ill. 185, 79 N.E.2d 593 (1948), cert. denied 335 U.S. 828 (1948); Nelson v. Mifler, 11 Ill.2d 378, 143 N.E.2d 673 (1957), where the court stated that if the non-resident defendant could show undue hardship in being sued in Illinois, the doctrine of forum non conveniens would provide him with adequate protection. 
the time of the James case Illinois courts were quite familiar with the doctrine of forum non conveniens ${ }^{22}$ and in addition, had been subject for a substantial period of time to a statutory policy which closed their doors to actions on outof-state deaths. ${ }^{23}$ On the other hand Michigan had a venue statute confining the remedy in actions against railroads to local courts, where the "line of ... [the] railroad traverses the county in which the plaintiff resides...."24 Michigan presumably had a policy of localizing these actions, and being the residence of the parties and the forum in which the cause of action arose, had an interest in applying that policy to this litigation. Illinois, not being the home of the decedent, his administratrix, or of the defendant, had no interest in applying its policy-assuming (without regarding its previous attitude in these matters) that it had a policy which necessitated the provision of a forum for this litigation. Aside from the essential requirement that a forum have an interest in the application of any policy which it may have, there are the requirements of the Full Faith and Credit Clause which

... ought not lightly to be set aside out of deference to a local policy which, if it exists, would seem too trivial to merit serious consideration when weighed against the policy of the constitutional provision and interest of the state whose judgment is challenged. ${ }^{25}$

It seems, therefore, that the requirements of the Full Faith and Credit Clause should not be set aside out of deference to a state policy which has as its only purpose the provision of a forum for all litigation without respect to the origin of the litigants or cause of action. Admittedly there are situations where a state's interest in the administration of its courts should not have to bow before the command of full faith and credit by yielding to the social and economic interests of a sister state. ${ }^{26}$ But it can hardly be contended that a policy which exposes courts to litigation between parties in whom they have not the slightest interest promotes efficiency or prevents abuse.

Four grounds are advanced, however, for denying full faith and credit to these injunctions: (1) If the courts of one state were required to dismiss an action because an injunction issued in a sister state restraining the prosecution of that suit, it would mean that the courts of the latter state could control what went on in the courts of the former. ${ }^{27}$ (2) If $\mathrm{F}_{2}$ recognized an injunction issued by

${ }^{22}$ See cases cited note 21 supra.

${ }^{23}$ III. Rev. Stat. (1951) c.70, \&2. This provision, however, was held to be in violation of the Full Faith and Credit Clause in First National Bank of Chicago v. United Air Lines, 342 U.S. 396 (1952). But compare Currie, The Constitution and the "Transitory" Cause of Action, to appear in Volume 73 of the Harvard Law Review.

24 Mich. Stat. Ann. (1957) \$27.641(3).

${ }^{25}$ Stone, J., in Milwaukee County v. M. E. White Co., 296 U.S. 268, 277 (1935).

${ }^{26}$ See Currie, The Constitution and the "Transitory" Cause of Action, to appear in Volume 73 of the Harvard Law Review.

${ }^{27}$ James v. Grand Trunk W. R. Co., 14 Ill.2d 156, 152 N.E.2d 858 (1958); Union Pacific R. Co. v. Rule, 155 Minn. 302, 193 N.W. 161 (1923); Reese, Full Faith and Credit to Foreign Equity Decrees, 42 Iowa L. Rev. 183 (1957). 
the courts of $F_{1}$ where the party restrained was a resident of $F_{2}$, it would violate the Privileges and Immunities Clause of the Constitution. ${ }^{28}$ (3) If full faith and credit need not be rendered to a statute prohibiting the export of causes of action, there is no reason why an equity decree which localizes causes of action should be given any greater recognition. ${ }^{29}$ (4) Since these judgments do not contain an adjudication of the merits of the ultimate controversy, they cannot be "judicial proceedings" for the purpose of recognition under the Full Faith and Credit Clause. ${ }^{30}$

The first argument against recognition concerns the interest of each state in determining the fairness or unfairness of any resort to its courts. It is assumed that the extension of full faith and credit to foreign injunctions would thwart this interest by the control which it would give the jurisdiction enjoining the action over the courts of the second state. ${ }^{31}$ That this argument is equally applicable to the many situations where full faith and credit must be accorded the judgments of a sister state casts doubt on its value as a justification for nonrecognition of foreign injunctions. Whether full faith and credit should be given these decrees would not seem to depend, therefore, on the fact that the courts of the rendering state will or will not control the courts of the recognizing state; it is based, rather, on the legitimacy of that control as determined by the competing policies and interests of these states. ${ }^{32}$ As exemplified by Rule and James, injunctions usually issue only where the enjoining jurisdiction has an interest and policy which warrants its providing a forum for the litigation and where the second state, having no legitimate interest and policy which necessitates its entertaining the suit, might properly dismiss the action on grounds of forum non conveniens..$^{33}$ The injunction cases, therefore, present a situation where the control exercised by the courts of one state over the courts of another state seems not to be improper.

28 U.S. Const. Art 4, §2. E.g., State ex rel. Bossung v. District Court, 140 Minn. 494, 168 N.W. 589 (1918).

${ }^{29}$ See James v. Grand Trunk W. R. Co., 14 Ill.2d 156, 152 N.E.2d 858 (1958); Union Pacific R. Co. v. Rule, 155 Minn. 302, 193 N.W. 161 (1923), both of which cases rely upon the Supreme Court decision in Tennessee Coal, Iron \& R. Co. v. George, 233 U.S. 354 (1914). But see Hovel v. Minneapolis \& St.L. Ry. Co., 165 Minn. 449, 452, 206 N.W. 710, 711 (1926), where it is observed that, "it would seem that, in the observance of principles of judicial comity, the judgments of the courts of a sister state should be more respected than a statute which can have no extraterritorial effect."

${ }^{30}$ See Union Pacific R. Co. v. Rule, 155 Minn. 302, 193 N.W. 161 (1923); Reese, op. cit. supra note 27 , at 198.

${ }^{31}$ James v. Grand Trunk W. R. Co.; 14 Ill.2d 156, 152 N.E. 2d 858 (1958); Reese, op. cit. supra note 27 , at 198 .

${ }^{32}$ See Currie, Full Faith and Credit to Foreign Land Decrees, 21 U. of Chi. L. Rev. 620, 643 (1954). The same reasoning may be applied to the question of extraterritorial recognition of injunctions against suit.

${ }^{33}$ For another example, see Bankers' Life Co. v. Loring, 217 Iowa 534, 250 N.W. 8 (1933), where a citizen of Iowa was enjoined by the courts of that state from suing another Iowa citizen in Minnesota,"under an insurance policy issued in Iowa. 
Resolution of this argument in favor of recognition, however, leaves three bases for non-recognition still standing. It is claimed that application of the Full Faith and Credit Clause to these judgments would violate the Privileges and Immunities Clause of the Constitution ${ }^{34}$ if a state court were to refuse jurisdiction to a non-resident plaintiff under the same circumstances in which it would grant jurisdiction to a resident plaintiff. Violation of the Privileges and Immunities Clause is based on the erroneous assumption, however, that the application of the Full Faith and Credit Clause to foreign injunctions would be restricted to those instances where a foreign suitor was the party enjoined. It is question begging, however, to predicate an argument against recognition on a misconstruction of the requirements of the constitutional provision requiring recognition. Application of the Full Faith and Credit Clause to these judgments would require a court to dismiss an action whose prosecution had been enjoined without regard to the residence of the party restrained. Conflict of the Full Faith and Credit Clause with the Privileges and Immunities Clause is even more unlikely in view of the Supreme Court's holding in Douglas v. New York, N.H. \& H.R. Co. ${ }^{35}$ There a New York court on the basis of a New York statute had refused jurisdiction of a suit between non-residents for personal injuries occurring outside that state. The Supreme Court in upholding a distinction between "residence" and "citizenship" as a basis for refusing jurisdiction, found no conflict with the Privileges and Immunities Clause in a discretionary refusal of jurisdiction to a non-resident. Since injunctions usually issue in stituations in which the court before whom the action is pending would be able to refuse jurisdiction on the basis of the Douglas rationale without violating the Privileges and Immunities Clause, no additional difficulty would seem to be presented because the forum in recognizing them is in effect accepting a foreign court's determination of its inappropriateness.

It is further contended, however, that since the United States Supreme Court in Tennessee Coal, Iron \& $R$. Co. v. George, ${ }^{36}$ determined that the Full Faith and Credit Clause did not require Georgia to recognize an Alabama statute denying a claimant's right to sue outside Alabama, that Clause does not require recognition of a decree which confines the remedy in a transitory cause of action to local courts. ${ }^{37}$ But it must be remembered that the require-

${ }^{34}$ U.S. Const. Art 4, \$2. See State ex rel. Bossung v. District Court, 140 Minn. 494, 168 N.W. 589 (1918); Gold Issue Mining \& Milling Co. v. Pennsylvania Fire Ins. Co., 267 Mo. 524, 184 S.W. 999 (1916); State ex rel. Pacific Mutual Life Ins. Co. v. Grimm, 239 Mo. 135, 143 S.W. 483 (1911).

3279 U.S. 377 (1929).

${ }^{36} 233$ U.S. 354 (1914). For an excellent analysis and critique of this case see Currie, op. cit. supra note 26.

${ }^{37}$ James v. Grand Trunk W. R. Co., 14 Ill.2d 356, 367, 152 N.E.2d 858, 864 (1958): "... we cannot escape the observation that if statutes prohibiting or circumscribing the export of causes of action may not be given extraterritorial effect, it is hard to see why an equity decree should be entitled to any greater recognition. A court should be subject to the same limitations." 
ments of full faith and credit with respect to sister state judgments and foreign statutes are not the same. It is clear, however, that full faith and credit requires that which has been adjudicated in one state to be res judicata to the same extent in every other. Although, for example, the Illinois court in the James case, might properly have denied recognition to the statute on which the Michigan injunction was founded, its rejection of that court's judgment was improper. ${ }^{38}$

Aside from the clear command of the Clause and its implementing statute in respect to "judicial proceedings," 39 it does not follow that because a state may not by statute confine a transitory cause of action to its own courts, a court of equity, with both parties before it, is prohibited from doing that which the legislature can not do by statute. The inability of legislation to anticipate the various situations which might arise, results in injustice to a plaintiff who must go outside the state where the cause of action arose in order to get jurisdiction of the defendant. No such objection applies to the localization of causes of action by injunction, since the enjoining court in rendering judgment has made a determination of the weight to be given the respective interests of the parties. ${ }^{40}$

Furthermore, the equating of exclusionary statutes with decrees restraining the export of causes of action, appears to be a repudiation of the Supreme Court's holding in Cole v. Cunningham, ${ }^{41}$ that the courts of one state may enjoin persons within their jurisdiction from prosecuting suits in another state. Even if it were assumed that the George case prohibited legislative localization of transitory causes of action ${ }^{42}$ and recognizing that the Cole case permitted courts this prerogative, it would not follow that the refusal to recognize decrees is necessitated by the denial of full faith and credit to statutes.

It is next argued that since these judgments do not contain an adjucciation of the merits of the ultimate controversy, they cannot be "judicial proceedings" for the purpose of recognition under the Full Faith and Credit Clause. ${ }^{43}$ From the contention that these judgments do not represent an adjudication of any personal or property rights between the parties, and thus courts of a second state can, by execution or other process, compel the defendant to render the money or property which he owes, it is reasoned that these judgments can only be enforced by imprisoning or otherwise punishing the defendant, and thus constitute an exception to the normal command of full faith and credit. ${ }^{44}$

${ }^{38}$ Magnolia Petroleum Co. v. Hunt, 320 U.S. 430, 437, 438, 439 (1943).

${ }^{39}$ See text at notes 8 and 9 supra.

${ }^{40}$ See Pound, The Progress of the Law-Equity, 33 Harv. L. Rev. 420, 426 (1920).

41133 U.S. 107 (1890).

12 See Tennessee Coal, Iron \& R. Co. v. George, 233 U.S. 354, 360 (1914), where the Court stated that "a State cannot create a transitory cause of action and at the same time destroy the right to sue on that transitory cause of action in any court having jurisdiction ... [under] the law of the court's creation. ..." See also Atchison, T. \& S. F. R. Co. v. Sowers, 213 U.S. 55 (1909).

${ }^{43}$ See authorities cited note 30 supra.

44 E.g., Union Pacific R. Co. v. Rule, 155 Minn. 302, 193 N.W. 161 (1923). 
An analysis of the cases, however, reveals that these decrees can be enforced abroad, by means other than punishing the defendant for contempt. ${ }^{45}$ The courts of Mississippi in Fisher v. Pacific Mutual Life Ins. Co., ${ }^{46}$ and Equitable Life Assurcince Soc. v. Gex' Estate ${ }^{47}$ enforced these foreign injunctions by dismissing the actions whose prosecution had been enjoined.

Resolution of the problem of the extra-state enforceability of these judgments, however, should not be separated from the question of whether they contain an adjudication of the merits of a controversy for the purpose of recognition under the Full Faith and Credit Clause. In Dobson ข. Pearce, ${ }^{48} \mathrm{~B}$ procured an injunction in Connecticut restraining A from enforcing a New York judgment which $A$ had procured by fraud. A thereupon attempted to enforce his judgment in New York but his action was dismissed by the New York court because

in the State of Connecticut ... the question of fraud would not be an open question between the parties, but would be considered entirely settled by the decree of the court of that state; and as full faith and credit are to be given by each state to the judicial proceedings of every other state, that is, the same credit, validity and effect as they would have in the state in which they were had, the parties are concluded in the courts of this state by the judgment of the court in Connecticut directly upon the question in issue. ${ }^{49}$

The injunction issuing in Dobson v. Pearce was not based on an adjudication of the ultimate substantive issues of the litigation; it was concerned merely with the question of fraud. Connecticut's finding as to the existence of fraud was thus treated as res judicata by the courts of New York. ${ }^{50}$ Thus when $B$ gets an injunction from the courts of $F_{1}$ restraining $A$ from suing in the courts of $F_{2}$ an adjudication has been made on the propriety of $A$ suing $B$ in $F_{2}$. Both $A$ and $B$ are before the court of $F_{1}$, which is being asked to enjoin the prosecution of the action in $F_{2}$. There is an opportunity for a full trial of the particular issue involved through pleadings, presentation of evidence and argument by both sides. The issuance or denial of the injunction is, then, a judgment on the merits.

In Dobson v. Pearce, the Connecticut court in enjoining A's suit on the New York judgment established a right in $\mathrm{B}$ of not having that judgment enforced against him. Similarly when $A$ is enjoined from prosecuting a suit against $B$ in

45 As in the case of foreign land decrees there is more than one possible means of enforcement. For example, when a court of $F_{1}$ orders $A$ to convey land in state $F_{2}$ to $B$, the courts of $F_{2}$, without punishing $A$ for contempt, can enforce that decree by vesting $B$ with title to the land. See Goodrich, Conflict of Laws 170 (3d ed., 1949).

46112 Miss. 30, 72 So. 846 (1916).

47184 Miss. 577, 186 So. 659 (1939).

48 N.Y. 156, 1Ab. Pr. 97 (1854). $\quad{ }^{9} \mathrm{Id}$., at 167 and 104.

${ }^{50}$ See Fidelity \& Deposit v. Gaston, Williams \& Wigmore, 13 F.2d 267 (S.D.N.Y., 1926), where plaintiff's failure to get the enforcement of a judgment against him enjoined was held by the second state to be res judicata as to the grounds for the first court's refusal to enjoin. 
$\mathrm{F}_{2}$, an equitable right has been established in $\mathrm{B}$ which would be infringed by the entertainment or continuance of the suit in $\mathrm{F}_{2 .}{ }^{51}$ As stated by Chief Justice Stone in Magnolia Petroleum Co. v. Hunt:

[A] litigation once pursued to judgment shall be as conclusive of the rights of the parties in every other court as in that where the judgment was rendered. . . Because there is a full faith and credit clause a defendant may not a second time challenge the validity of the plaintiff's right which has ripened into a judgment and a plaintiff may not for his single cause of action secure a second or a greater recovery. ${ }^{62}$

That a judgment, in order to be res judicata as to the issues decided, need not contain an adjudication of all the merits in a controversy is clear from the Supreme Court's decision in Angel v. Bullington..$^{53} \mathrm{It}$ was there stated that it is a "misconception of res judicata to assume that the doctrine does not come into operation if the court has not passed on the 'merits' in the sense of the ultimate substantive issues of a litigation." ${ }^{44} \mathrm{~A}$ judgment restraining a person from suing outside the enjoining jurisdiction, being an adjudication of certain issues, is a "judicial proceeding" for purposes of the Full Faith and Credit Clause and therefore must be given res judicata effect by the courts of a sister state..$^{55}$

It is not proposed that the extention of full faith and credit to these judgments be founded on the apparent absence of valid arguments against recognition. Nor is it supposed that affirmative argument can properly be restricted to a restatement of the requirements of the Full Faith and Credit Clause and its implementing statute with respect to "judicial proceedings." It is suggested, however, that since foreign injunctions cannot meaningfully be distinguished from other judgments, they cannot properly be made an exception to the normal command of full faith and credit.

${ }^{51}$ E.g., Brownell v. Chase Nat'l Bank, 352 U.S. 36, 38 (1956); Stratter v. Stratter, 2 N.Y.2d 668,143 N.E.2d 10 (1957).

52320 U.S. $430,439-40$ (1943).

${ }^{5} 330$ U.S. 183 (1947). The North Carolina Supreme Court, although not adjudicating the merits "in the sense of the ultimate substantive issues" (Rest., Judgments $\$ 4$, Comment a [1942]; Smith v. McNeal, 109 U.S. 426 [1883]), was determining the merits in the sense of the "jurisdictional merits" and it can no longer be doubted that "the principles of res judicata apply to questions of jurisdiction as well as to other issues," whether or not jurisdiction is assumed or denied. Treinies v. Sunshine Mining Co., 308 U.S. 66, 78 (1939) (where the assumption of jurisdiction was considered res judicata). See Ripperger v. A. C. Allyn \& Co., 113 F.2d 332 (C.A.2d, 1940), cert. denied 311 U.S. 695 (1940) (where the denial of jurisdiction was held to be res judicata). Further explanation of this principle may be found in Mr. Justice Traynor's dissent in Kubon v. Kubon, 331 P.2d 636, 638 (Cal., 1958), and in Stucker v. County of Muscatine, 87 N.W.2d 452 (Iowa, 1958).

64 Angel v. Bullington, 330 U.S. 183, 190 (1947).

${ }^{55}$ See Green v. Van. Buskirk, 5 Wall. (U.S.) 307 (1866); Green v. Van Buskirk, 7 Wall. (U.S.) 139 (1868) (full faith and credit to "judicial proceedings"); Sanders v. Armour Fertilizer Works, 292 U.S. 190 (1934) (garnishment proceeding held entitled to recognition); Swenson, Conflict of Laws Problems under the Iowa Garnishment Statutes, 34 Iowa I. Rev. 605,632 (1949). 